\title{
PENGOLAHAN AIR PAYAU MENGGUNAKAN ELEKTRODIALISIS DAN OZON
}

\author{
Ulvi Pri Astuti * \\ *Politeknik Perkapalan Negeri Surabaya \\ ulvipriastuti@gmail.com
}

\begin{abstract}
Abstrak
Electrodialysis (ED) merupakan teknologi yang hampir sama dengan RO tapi biaya investasi dan operasionalnya lebih rendah. ED berfungsi untuk meremoval TDS yang tinggi dalam air payau. Akan tetapi ED tidak difungsikan untuk meremoval mikroorganisme yang terdapat di air payau sehingga ditambahkan pengolahan menggunakan ozon sebagai desinfektan. Permasalahan yang akan dibahas dalam paper ini adalah menganalisis efektivitas kombinasi dari ED dan Ozon dalam pengolahan air payau menjadi air tawar. Dalam paper ini terdapat 3 variabel yaitu variabel debit dalam ED (0,67 L/jam, 0,17 L/jam, dan 0,13 L/jam), tegangan (6, 9, dan $12 \mathrm{~V})$, dan waktu pemaparan ozon (5 menit dan $\mathrm{Q}_{\text {reaktor }}$ ). Variabel yang paling berpengaruh adalah waktu detensi ED. Semakin lama waktu detensinya maka menghasilkan kualitas air produk yang paling baik. Efektivitas kombinasi ED dan ozon dilihat dari variasi yang menghasilkan kualitas air terbaik dan konsumsi energinya tidak terlalu besar, sehingga didapatkan variasi yang efektif adalah variasi debit 0,13 L/jam pada tegangan $6 \mathrm{~V}$ dan lama waktu pemaparan ozon yaitu selama 5 menit.
\end{abstract}

Kata kunci : Desalinasi, Electrodialysis (ED), Ozon

\begin{abstract}
Electrodialysis (ED) is a technology that similar to the RO but the investment and operational costs are lower. ED serves to meremoval high TDS in brackish water. But ED is not enabled for meremoval microorganisms found in brackish water so the added processing using ozone as a disinfectant. Issues to be discussed in this paper is to analyze the effectiveness of the combination of ED and Ozone in the processing brackish water into fresh water. In this paper there are three variables: the variable discharge in the $\operatorname{ED}(0.67 \mathrm{~L} / \mathrm{h}, 0.17 \mathrm{~L} / \mathrm{hr}$, and $0.13 \mathrm{~L} / \mathrm{h})$, voltage $(6$, 9, and $12 \mathrm{~V}$ ), and ozone exposure time (5 minutes and Qreaktor). The most influential variable is the detention time of ED. The longer the detention time, the water quality produce the best product. The effectiveness of the combination of ED and ozone views of variations that produce the best water quality and consumption of energy is not too big, so we get effective variation is debit variation of $0.13 \mathrm{~L} / \mathrm{h}$ at a voltage of $6 \mathrm{~V}$ and the duration of exposure of ozone, which is 5 minutes.
\end{abstract}

Keywords: Desalination, Electrodialysis (ED), Ozone

\section{PENDAHULUAN}

Daerah Pesisir di Negara-negara maju (el Paso dan Texas, Uni Emirat Arab, Inggris, Israel, Trinidad, Cyprus) yang mengalami permasalahan air bersih mengatasinya dengan teknologi desalinasi (Badan Lingkungan Hidup, 2012). Teknologi yang paling banyak digunakan adalah teknologi Reverse Osmosis (RO) yaitu sebesar 32\% (Eltawil et al., 2009).

Teknologi RO adalah salah satu teknologi yang paling efektif dalam mengolah air payau menjadi air tawar karena menggunakan membran yang dapat menurunkan kadar garam hingga (88-95)\% (Said, 2003). Akan tetapi RO membutuhkan energi yang tinggi dan biaya operasional yang cukup besar sehingga kurang sesuai untuk masyarakat pesisir Indonesia. Daerah pesisir di Indonesia dikenal sebagai daerah miskin. Berdasarkan data dari Badan Pusat Statistik (BPS) menyebutkan bahwa
25,14\% dari total penduduk miskin nasional bertempat tinggal di daerah pesisir (Peraturan Menteri Kelautan dan Perikanan RI, 2013).

Teknologi yang hampir sama dengan prinsip RO adalah teknologi Elektrodialisis (ED). Kedua teknologi ini merupakan teknologi yang cukup bersaing karena sama-sama menggunakan membran dalam prosesnya (Eltawil et al., 2009). Kelebihan ED dibandingkan dengan RO dalam hal tekanan, penggunaan membran, dan biaya investasinya. Tekanan yang dibutuhkan ED lebih rendah daripada RO dan kemampuan membrannya lebih tahan lama dibandingkan RO karena proses ED dapat meminimalkan terjadinya fouling pada membran. Selain itu, biaya investasi dan operasional tidak sebesar RO dikarenakan penggunaan bahan kimia pada pretreatment lebih sedikit dan energi yang digunakan adalah energi listrik Akan tetapi, ED 
tidak difungsikan untuk meremoval mikroorganisme sehingga diperlukan pengolahan tambahan (Valero et al., 2010).

Ozon merupakan salah satu desinfektan yang mampu mendegradasi senyawa-senyawa organik, menghilangkan warna, bau, dan rasa (Bismo et al., 2008). Selain itu, ozon merupakan teknologi yang ramah lingkungan karena sebelum atau setelah bereaksi dengan unsur lain, ozon akan menghasilkan oksigen (O2) (Purwadi et al., 2003). Efektivitas desinfeksi tergantung pada kerentanan dari organisme target, waktu detensi, dan konsentrasi ozon (Solomon et al., 1998). Permasalahan yang akan dibahas dalam paper ini adalah menganalisis efektivitas kombinasi dari ED dan Ozon dalam pengolahan air payau menjadi air tawar. Variabel yang digunakan dalam penelitian ini meliputi variabel debit, tegangan, dan waktu pemaparan ozon.

\section{METODE PENELITIAN}

\subsection{Alat dan Bahan}

\subsubsection{Alat}

Alat yang digunakan adalah :

\section{Paket Reaktor}

Reaktor yang digunakan dalam penelitian ini terbuat dari bahan akrilik berbentuk persegi panjang dengan dimensi luar $24 \mathrm{~cm}$ x $9 \mathrm{~cm}$ x $2 \mathrm{~cm}$, sedangkan dimensi dalam $20 \mathrm{~cm}$ x 5 cm x $2 \mathrm{~cm}$. Reaktor didesain dengan sistem tertutup dalam skala laboratorium. Selain itu, terdapat pengapit reaktor yang terbuat dari akrilik dan berbentuk persegi panjang dengan dimensi $24 \mathrm{~cm} \times 13 \mathrm{~cm} \times 2 \mathrm{~cm}$. pengapit ini terdapat pada bagian luar

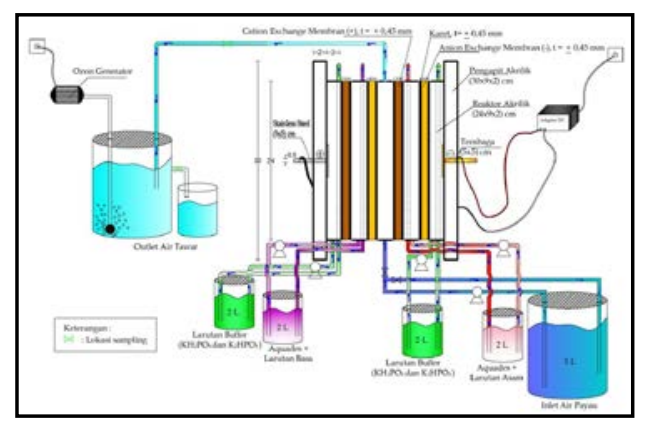

Gambar 1. Reaktor ED dan Ozon

2. Membran

Membran yang digunakan ada dua, yaitu Cation Exchange Membrane (CEM/+) dan
Anion Exchange Membrane ( AEM/-) dengan dimensi $24 \mathrm{~cm}$ x $9 \mathrm{~cm}$. Membran AEM dan CEM terbuat dari kombinasi gel polystyrene dan divinylbenzene.

3. Pompa resirkulasi

Pompa berfungsi untuk memompa air baku ke dalam reaktor. Pompa yang digunakan adalah pompa submersible yang memiliki spesifikasi debit $200 \mathrm{~L} / \mathrm{jam}$ atau 0,003 $\mathrm{mL} / \mathrm{menit}$. Dalam penelitian ini pompa resirkulasi yang digunakan terdapat 5 buah yang terdiri dari tiga pompa debit $200 \mathrm{~L} / \mathrm{jam}$ dan 2 pompa debit 250 L/jam.

4. Adaptor

Adaptor yang digunakan adalah adaptor DC yang memiliki batas hingga 12 volt dan memiliki kekuatan arus sebesar 2 A. Adaptor berfungsi sebagai sumber aliran listrik pada proses ED.

5. Anoda dan Katoda Stainless steel berfungsi sebagai katoda dan tembaga berfungsi sebagai anoda dengan ukuran masing-masing $5 \times 5 \mathrm{~cm}$.

6. Multimeter

Multimeter berfungsi untuk mengukur kuat arus (I) dan tegangan yang dialirkan

7. Kabel dan Selang Medis

Selang medis yang digunakan terbuat dari silikon yang tahan terhadap asam kuat dan basa kuat. Selain itu juga dapat digunakan selang biasa.

8. Tangki Reservoir Tangki sebagai tempat penyimpanan air umpan dan sebagai bak resirkulasi.

9. Ozon Generator

Ozone Generator yang digunakan adalah Ozonizer dengan spesifikasi RESUN RSO25 series kapasitas 0,25g/jam.

\subsubsection{Bahan}

Bahan yang digunakan adalah :

1. Air Baku dari air payau

Air baku diambil dari air sumur di Pulau Mandangin dengan TDS $10.000 \mathrm{mg} / \mathrm{L}$, kemudian diencerkan hingga range TDS $2.000-2.300 \mathrm{mg} / \mathrm{L}$

2. Lem Sealant, berfungsi sebagai perekat antar kompartemen untuk menghindari kebocoran.

3. Aquades berfungsi sebagai flushing, sehingga ion-ion pada elektrolit pekat dapat diresirkulasi dengan bantuan aquades.

4. Larutan penyangga PO4 berfungsi untuk menjaga $\mathrm{pH}$ dalam kompartemen elektroda tetap netral, sehingga elekroda tahan lama. Larutan penyangga yang digunakan adalah larutan $\mathrm{KH}_{2} \mathrm{PO} 4$ dan $\mathrm{K}_{2} \mathrm{HPO} 4$. 


\subsection{Pelaksanaan Penelitian}

\subsubsection{Variabel Penelitian}

Variabel yang digunakan dalam penelitian ini ada 3 aspek, yaitu :

1. Variabel Debit di ED

Debit yang digunakan adalah $\mathrm{Q}_{1}=0,67$

$\mathrm{L} / \mathrm{jam}, \mathrm{Q}_{2}=0,17 \mathrm{~L} / \mathrm{jam}$, dan $\mathrm{Q}_{3}=0,13$ $\mathrm{L} / \mathrm{jam}$.

2. Variabel Tegangan/ Voltase Variasi tegangan yang digunakan adalah 6 $\mathrm{V}, 9 \mathrm{~V}$, dan $12 \mathrm{~V}$

3. Variabel Waktu Pemaparan Ozon

Variasi waktu pemaparan ozon ada dua yaitu 5 menit dan waktu pemaparan ozon sama dengan waktu detensi ED (7,42 jam, 28,72 jam, dan 38 jam).

\subsubsection{Persiapan Pelaksanaan}

Persiapan yang dilakukan sebelum melakukan penelitian adalah sebagai berikut :

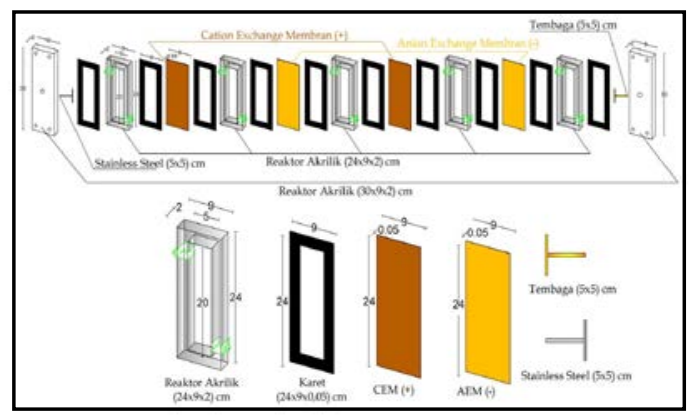

Gambar 2. Pemasangan Reaktor ED

2. Melakukan pre-conditioning terhadap membran dengan cara merendamnya terlebih dahulu dengan konsentrasi $\mathrm{NaCl} 5 \%$ pada temperature $40^{\circ} \mathrm{C}$ selama 24 jam supaya mengalami ekspansi sehingga larutan elektrolit dapat melewati membran.

3. Melakukan uji kebocoran terhadap reaktor yang dipakai

\subsubsection{Pelaksanaan Penelitian}

Tahapan- tahapan yang dilakukan selama penelitian adalah :

1. Mengisi tangki reservoir dengan larutan buffer/penyangga yang terbuat dari campuran $\mathrm{KH}_{2} \mathrm{PO} 4$ dan $\mathrm{K}_{2} \mathrm{PO} 4$ (ada sebanyak 2 buah dan masing- masing diisi sebanyak 2 L) dan aquades (ada sebanyak 2 buah dan masing- masing diisi sebanyak 2 L), air payau sebanyak $5 \mathrm{~L}$.
2. Melakukan pengaturan valve sesuai dengan debit yang akan digunakan dalam penelitian pendahuluan. Pengaturan debit diatur secara manual dengan membuka/ menutup valve untuk memperbanyak/ mengurangi jumlah air yang masuk ke dalam ED.

3. Mengisi reaktor ED hingga penuh untuk tiap kompartemennya dengan urutan dari kompartemen kiri ke kanan adalah larutan buffer/penyangga dan aquades, air payau, aquades, dan larutan buffer/penyangga. Ini merupakan titik awal pengoperasian reaktor

4. Menyalakan pompa submersible yang terletak di tangki air payau, aquades, dan larutan penyangga.

5. Menyalakan Adaptor untuk memberikan tegangan dengan variasi tegangan yang berbeda-beda yaitu 6, 9, dan 12 Volt untuk tiap variasi waktu detensi di ED dan ozon. Arus listrik dialirkan melalui katoda dan anoda dimana katoda kutub (-) dan anoda kutub (+). Kemudian menyalakan pompa di bak larutan penyangga.

6. Melakukan uji parameter yang terdiri dari DHL, TDS, salinitas, pH, klorida, zat organik, dan total koliform. Pengukuran dilakukan pada bak inlet dan bak outlet untuk melakukan perbandingan kualitas air.

\section{HASIL DAN DISKUSI}

\subsubsection{Pengaruh Tegangan dan Waktu Detensi Terhadap Persentase Removal TDS}

Faktor yang berpengaruh adalah tegangan dan waktu detensi. Berikut ini hasil analisi variasi tegangan dan waktu detensi pada reaktor ED untuk analisa TDS yang terdapat pada Gambar 3.

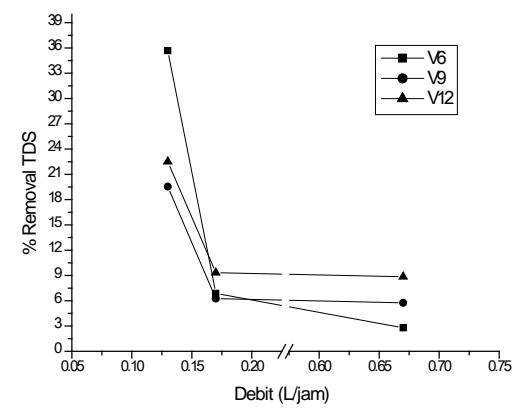

Gambar 3. Removal TDS pada outlet ED

Pada Gambar 3. menunjukkan bahwa pada tegangan $6 \mathrm{~V}$ terjadi perubahan drastis pada debit $0,13 \mathrm{~L} / \mathrm{jam}$ untuk persentase removal TDS. Persentase removal yang awalnya $2.78 \%$ pada debit $0,67 \mathrm{~L} / \mathrm{jam}$ menjadi $6.88 \%$ pada 
debit 0,17 L/jam, sedangkan pada debit 0,13 $\mathrm{L} /$ jam persentase removalnya langsung menjadi 35.68\%. Sedangkan pada tegangan 9V dan $12 \mathrm{~V}$ kenaikan persentase removal yang terjadi tidak sedrastis pada tegangan $6 \mathrm{~V}$ dan persentase removalnya pun tidak sebesar tegangan $6 \mathrm{~V}$. Persentase removal TDS maksimum untuk tegangan $9 \mathrm{~V}$ adalah $19.55 \%$, dan untuk tegangan $12 \mathrm{~V}$ sebesar 22.51\%. Pada debit $0,67 \mathrm{~L} /$ jam persentase removal untuk $6 \mathrm{~V}$ adalah persentase removal terendah dibandingkan yang lain, akan tetapi ketika debit 0,13 L/jam persentase removal tertinggi terjadi pada tegangan 6V. Hal ini menunjukkan bahwa waktu detensi lebih memberikan pengaruh dibandingkan tegangan.

\subsubsection{Pengaruh Tegangan dan Waktu Detensi terhadap Persentase Removal Salinitas}

Salinitas adalah garam terlarut dalam air yang merupakan bagian dari TDS, salinitas pada air payau dapat berkurang jika melewati membran diantara kedua elektroda. Hasil analisis salinitas pada berbagai variasi tegangan terdapat pada Gambar 4.

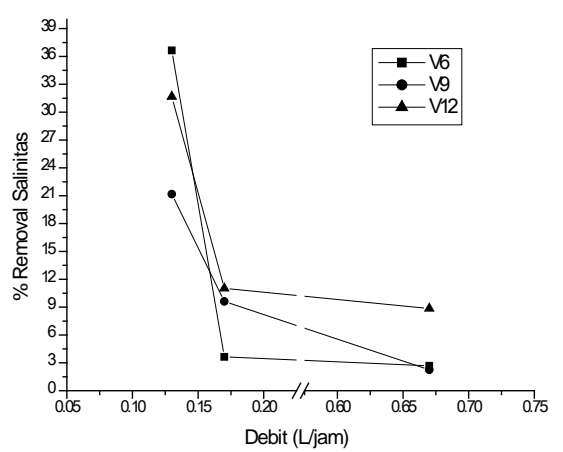

Gambar 4. Removal Salinitas pada outlet ED

Gambar 4. menunjukkan hasil yang sama seperti pada analisa TDS, yaitu tegangan yang paling maksimal adalah $6 \mathrm{~V}$ pada debit 0,13 L/jam. Hal ini dikarenakan salinitas merupakan bagian dari TDS sehingga menunjukkan hasil yang linier. Trend yang ditunjukkan oleh grafik pada Gambar 4. juga menunjukkan perubah drastis yang terjadi pada tegangan $6 \mathrm{~V}$. Hal ini semakin membuktikan bahwa pada reaktor ED dalam penelitian ini hal yang lebih berpengaruh adalah waktu detensi dibandingkan dengan tegangan. Persentase removal maksimum yang didapatkan untuk tiap tegangan terjadi pada waktu detensi paling lama yaitu 38 jam yaitu sebesar $36.65 \%$ pada tegangan $6 \mathrm{~V}, 21.17 \%$ untuk tegangan $9 \mathrm{~V}$, dan $31.67 \%$ pada tegangan $12 \mathrm{~V}$.

\subsubsection{Pengaruh Tegangan dan Waktu Detensi terhadap Persentase Removal Klorida}

Tegangan menjadi salah satu faktor yang menjadi variabel dalam penelitian ini dikarenakan ingin menganalisis tegangan optimum agar didapatkan kualitas air produk yang paling baik. Hasil analisis TDS dan salinitas pada berbagai variasi tegangan menunjukkan hal yang sama yaitu tegangan yang maksimal adalah 6V. sementara itu untuk hasil analisis klorida terdapat pada Gambar 5.

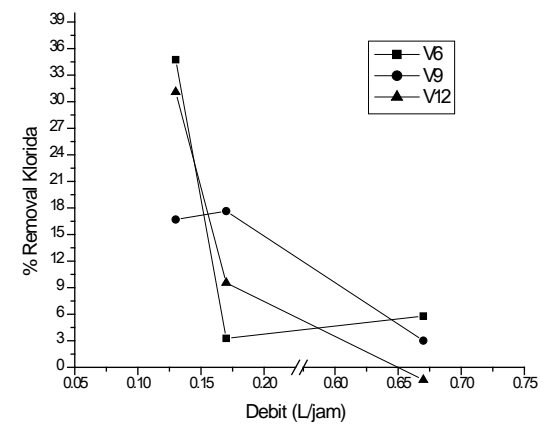

Gambar 5. Removal Klorida pada outlet ED

Gambar 5. menunjukkan bahwa persentase removal klorida tertinggi terdapat pada tegangan $6 \mathrm{~V}$ pada debit $0,13 \mathrm{~L} / \mathrm{jam}$ yaitu sebesar $34.75 \%$. Sementara itu, persentase removal maksimum untuk tegangan $9 \mathrm{~V}$ adalah $17.65 \%$ pada debit $0,17 \mathrm{~L} / \mathrm{jam}$, dan pada tegangan $12 \mathrm{~V}$ persentase removal maksimum adalah $31.09 \%$ pada debit 0,13 L/jam. Hal ini sedikit berbeda dengan trend pada persentase removal TDS dan Salinitas. Salah satu penyebabnya adalah adanya unsur pengganggu ketika melakukan analisis. Akan tetapi, trend pada tegangan 6V sama dengan persentase removal TDS dan Salinitas yaitu sama-sama menunjukkan perubahan yang drastis pada debit 0,13 L/jam.

Selama penelitian berlangsung, membran paling sering mengalami fouling terjadi pada tegangan $12 \mathrm{~V}$ pada debit 0,17 L/jam dan 0,13 L/jam, pada tegangan $9 \mathrm{~V}$ debit $0,13 \mathrm{~L} / \mathrm{jam}$. Membran yang mengalami fouling adalah membran yang berdekatan dengan elektroda. Kondisi seperti ini sangat rawan terjadi membran fouling, oleh karena itu, $\mathrm{pH}$ disekitar elektroda perlu dijaga agar terdapat disekitar 7, apabila $\mathrm{pH}$ sudah berubah drastis dengan tegangan yang besar, maka fouling pada membran akan cepat terjadi. Kondisi $\mathrm{pH}$ disekitar elektroda dapat dijaga dengan cara memutar outlet pada kompartemen buffer 1 dengan kompartemen buffer 2 . Hal ini dapat mencegah terjadinya perecepatan fouling pada membran. 
Dari ketiga hasil analisis kualitas air produk dapat diambil kesimpulan bahwa tegangan yang maksimum adalah 6V. Faktor yang lebih berpengaruh terhadap kualitas air produk pada reaktor ED dengan desain seperti pada Gambar 3 hingga Gambar 5 adalah waktu detensi. Penambahan tegangan yang diberikan pada reaktor tidak terlalu memberikan pengaruh dibandingkan tegangan awal yaitu 6V.

\subsection{Efektivitas Ozon dalam Meremoval Total Koliform}

Setelah melewati proses ED, air produk akan masuk ke dalam reaktor selanjutnya yaitu ozon. Reaktor ini berfungsi untuk membunuh mikroorganisme yang terdapat dalam air baku air payau. Parameter yang digunakan untuk mengetahui removal mikroorganisme dalam reaktor ozon adalah Total Koliform. Bakteri koliform merupakan mikroorganisme indikator yang digunakan untuk mengatahui efektivitas ozonisasi. Hasil analisis bakteri koliform terdapat pada Gambar 6.

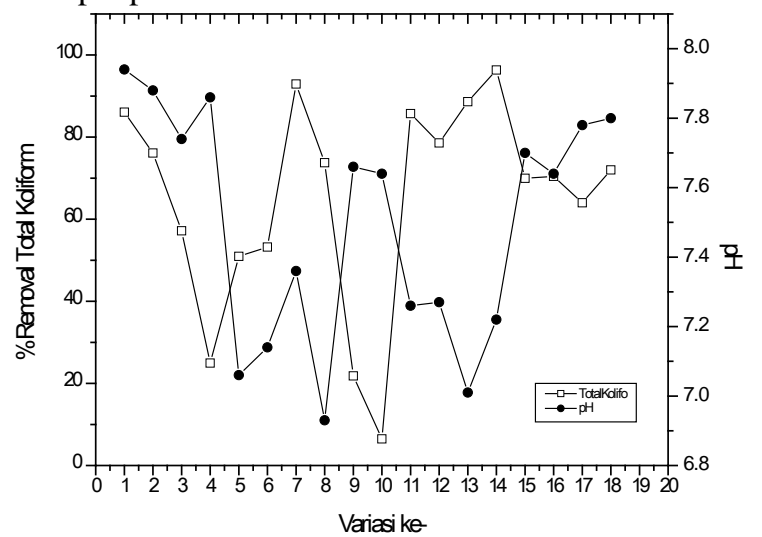

Gambar 6. Persentase Removal Total Koliform di Air baku

Berdasarkan pada Gambar 6. didapatkan bahwa persentase maksimum removal total koliform adalah 92,92\% yaitu pada debit 0,17 L/jam dengan variasi waktu pemaparan ozon selama 5 menit. Hasil penelitian menunjukkan bahwa proses ozonisasi lebih maksimum ketika lama waktu pemaparan ozon yaitu 5 menit, sedangkan untuk ozon yang terus dinyalakan selama proses, persen removalnya lebih kecil dibandingkan dengan waktu pemaparan 5 menit.

Salah satu faktor yang mempengaruhi pertumbuhan mikroorganisme adalah $\mathrm{pH}$. Pada Gambar 6 menunjukkan bahwa pH berbanding terbalik dengan persentase removal total Koliform. Hal ini dikarenakan mikroorganisme lebih cenderung dapat bertahan pada $\mathrm{pH}$ asam, sehingga ketika pHnya mendekati basa, persentase removalnya menjadi turun,sedangkan ketika dalam reaktor ED pHnya bersifat asam maka persentase removalnya menjadi naik.

\section{KESIMPULAN}

Kesimpulan dari paper ini adalah :

1. Tegangan memberikan pengaruh terhadap kualitas air akan tetapi yang lebih berpengaruh adalah waktu detensi dalam proses ED. Hal ini dibuktikan dengan tegangan maksimum yang dapat menghasilkan kualitas air produk yang paling baik adalah 6V dibandingkan dengan tegangan $9 \mathrm{~V}$ dan $12 \mathrm{~V}$ yaitu pada debit 0,13 L/jam dengan persentase removal TDS sebesar 35,68\%, Salinitas 36,65\%, dan Klorida sebesar 34,75\%.

2. Efektivitas kombinasi ED dan ozon dilihat dari variasi yang menghasilkan kualitas air terbaik dan konsumsi energinya tidak terlalu besar, sehingga didapatkan variasi yang efektif dalam penelitian ini adalah variasi debit 0,13 L/jam pada tegangan $6 \mathrm{~V}$ dan lama waktu pemaparan ozon yaitu selama 5 menit.

\section{PENGHARGAAN}

Penulis menyampaikan terimakasih yang sebesar-besarnya kepada Alfan Purnomo, ST., MT., dan Arseto Yekti Bagastyo, ST, MT., Mphil., Ph.D atas bantuan dana penelitian ini serta kepada Ayah dan Ibu atas dukungan dana dan doa. Penulis juga menyampaikan terima kasih kepada Suherman Hidayat yang membantu penulis dalam menyediakan air baku untuk penelitian.

\section{DAFTAR PUSTAKA}

[1] Badan Lingkungan Hidup. (2012). Desalinasi Memanfaatkan Air Laut untuk Air Minum. Badan Lingkungan Hidup Kabupaten

Grobogan.(online).http://blh.grobogan.go.i d/artikel/217-desalinasi-memanfaatkan-air laut-untuk-minum.html.

[2] Bismo, S, Indar K., Jayanudin, Febri H., dan Hergi J. S., (2008). Studi Awal Degradasi Fenol dengan Teknik Ozonasi di dalam Reaktor Annular. Semarang: Universitas Diponegoro

[3] Eltawil, M. A. Zhao Z., Liqiang Y. (2009). A Review of Renewable Energy Technologies Integrated with Desalination System. Elsevier : Renewable and 
Sustainable Energy Review 13 (2009) 2245-2262.

[4] Peraturan Menteri Energi dan Sumber Daya Mineral. (2014). Peraturan Menteri Energi dan Sumber Daya Mineral No.19 Tahun 2014 tentang Perubahan atas Peraturan Menteri Energi dan Sumber Daya Mineral No. 9 Tahun 2014 tentang Tarif tenaga listrik yang disediakan oleh Perusahaan Perseroan (Persero) Perusahaan Listrik Negara. Jakarta

[5] Peraturan Menteri Kelautan dan Perikanan. (2013). Peraturan Menteri Kelautan Dan Perikanan Republik Indonesia. Nomor 2/Permen-Kp/2013 Tentang Pedoman Pelaksanaan Program Nasional Pemberdayaan Masyarakat Mandiri Kelautan Dan Perikanan, Jakarta.

[6] Said, N., I. (2003). Aplikasi Teknologi Osmosis Balik untuk Memenuhi Kebutuhan Air Minum di Kawasan Pesisir atau Pulau Terpencil. BPPT : Kelompok Teknologi Pengelolaan Air Bersih dan Limbah Cair, Pusat Pengkajian dan Penerapan Teknologi Lingkungan.

[7] Solomon, C., Peter C., Collen M., dan Andrew L. (1998). Ozone Disinfection. U.S. Environmental Protection Agency under Assistance Agreement No. CX824652. National Small Flows Clearinghouse.

[8] Valero, F., Barcelo A., and Arbos R. 2011. Electrodialysis technology: theory and application. Desalination, Trends and Technology. Michael Schorr (Ed.) Spain. 